\title{
From "Normative Power" to "Global Governmentality": An Assessment of European Union's Engagement of Civil Society in Indonesia ${ }^{1}$
}

\author{
Ahmad Rizky Mardhatillah Umar
}

\begin{abstract}
This article develops a theory of European power as 'governmentality', with a particular reference to European Union (EU)'s engagement of civil society in Indonesia through a package of "civil society strengthening programs". In contrast to some arguments of 'normative power' or 'civilian power' in the European Union, that put emphasis on EU's normative framework in explaining EU's diplomatic engagements in world politics, this article argues that European Union's global outreach is best seen as the politics of governmentality, which comprises the spread of norms to the "global south" through various developmental strategies in order to form particular subjectivities based on European Union's "normative framework". This argument will be applied to empirically explain the role of EU's engagement of civil society in Indonesia. To substantiate the argument, this article will analyse (1) the debate on recent theorisation of "European power" in EU and International Relations studies, with a reference to Ian Manners' conception of "Normative Power Europe"; (2) the snapshot of European Union's key policies on International Development Assistance in Indonesia; and (3) the case of some projects related to "civil society strengthening programs" in Indonesia.
\end{abstract}

Keywords: European Union; civil society; international development; democracy promotion; normative power; global governmentality.

\section{Introduction}

The European Union (EU) has been widely acknowledged as one of the largest political entities in the world since its early formation in the late 1990s. In his famous article titled, Journal of

\footnotetext{
Parts of this article were presented at the 3rd Convention of European Studies (Yogyakarta, May 2014) and appeared at Short Film "EU Democracy Promotion: What It is and Why It Matters" (Sheffield, June 2016). The author wishes to thank Muhadi Sugiono, Arie Ruhyanto, Yunizar Adiputera, Suci Lestari Yuana, Farieda Ilhami Zulaikha, Annisa Maulia Fahmi, and the reviewers for insightful comments and Paul James Cardwell for allowing the author to contribute some thoughts to his film.
} 
Common Market Studies, Ian Manners coined the term 'Normative Power' to explain how the European Union established itself as one of the major forces in world politics. Since its foundation, according to Manners (2002), 'norms' have been central to EU's foreign policy and EU's relations with other political forces, which distinguishes the base of EU power from other major powers in international politics such as the United States, China, or Russia. The strength of EU power, according to Manners, is the ability to define 'what is normal' in world politics in a way that determines the structure of 'normative order' for the world (see also Manners, 2006). For example, one of EU's values - which was defined by Manners as 'norms'-is democracy and good governance, which EU has attempted to spread to large parts of the 'global south' through international development assistance and democracy promotion (see Gillespie \& Young, 2002; Carbone, 2010). Through such international engagements, EU has been widely involved in providing development assistances to many countries that are on their way to the so-called 'democratic transition'.

This article attempts to critically engage Manners' argument of 'normative power Europe' by exploring EU's role in international development assistances through an alternative framework, namely "governmentality". Kicked-off by French philosopher Michael Foucault in one of his articles (1991), this concept has gained prominence in recent International Relations theoretical debates (see Neumann \& Sending, 2010; Joseph, 2012; Vrasti, 2013; Chandler \& Richmond, 2015; Hamilton, 2014; Kiersey \& Stokes, 2013; Umar, 2016). This framework will be applied to further understand the politics and practice of EU's international development assistance and democracy promotion in Post-New Order Indonesia, in which EU has been engaged during the democratic transition since 1998. More specifically, this article will analyse some of EU's projects related to "Civil Society Strengthening Programs", which is the core of EU's main approach in promoting democracy, good governance, and Human Rights in Indonesia. 
Applying the theory of "governmentality" as an alternative approach in understanding EU power does require some discussion on how such projects are able to structurally define not only "what is normal" in world politics, but also on specific techniques used by EU to craft a particular subjectivity that is inherent with the framework that EU holds in its foreign policy. It therefore needs a further analysis of both ideational and material forms of EU power (see Joseph \& Bulmer 2016). Against this backdrop, this article will elaborate how EU supported Indonesian civil society to conduct some empowerment or advocacy activities by providing external helps, particularly financial assistance. In this context, this article will raise two questions: (1) How is the relationship between the European Union and civil society organisations in EU's programs able to strengthen civil society in Indonesia?; and (2) How does EU's engagement of civil society in Indonesia incorporate the EU's norms and values into Indonesian governments and civil society organisations through EU-funded projects?

The argument of this article will be developed in five sections. The first section will provide some introductory remarks of this article. The second section will reconceptualise 'European Power' through the prism of "governmentality" by engaging the idea of 'normative power' developed by Ian Manners. The third section will provide a snapshot of EU's civil society strengthening programs, which are arguably embedded with EU's international development and democracy promotion strategies in the global south. The fourth section will assess how the EU's civil society strengthening programs in Indonesia portray EU's global governmental project in world politics, which locates Indonesian civil society in the global power nexus between 'international development' and 'global liberal governmentality' projected by the EU. The fifth section will provide conclusions and interesting insights into EU's use of normative power. 


\section{Reconceptualising European Power: "Governmentality" Approach}

This section will theoretically engage with Ian Manners' conception of 'normative power', provide some critical readings concerning this concept, and offer "governmentality" as an alternative approach to understand EU power. The argument of this section will proceed in two parts. While the first part will explain the idea of "Normative Power" in the understanding of EU power, the second part will develop a framework of global governmentality to sketch EU's international development projects in the global south.

\section{1. "Normative Power Europe" and the Contending Perspective on EU's Global Engagements}

In the dominating Realist perspectives of International Relations, "power" is defined in terms of 'material power' such as military or the political and economic size of a country (Morgenthau, 1956; Mearsheimer 2001). Practically, this concept of power is manifested into the form of 'militarism', which relates to the practice of influencing other states through military forces, defence systems, and many other 'harsh' sources of power (see Morgenthau, 1956). This concept of 'power' is challenged by the concept of 'soft power', that is according to Nye (2002), not only characterized by military power, but also the ability to influence by cultural-economic sources of power. Thus, "power" can be redefined, not only in the context of 'political power' but also cultural power that one state owns. This dimension of power, according to Manners (2002), gives some moral intentions to stop the fragility of statehood relations that results from the realist perspectives on power.

One could argue, however, that norms cannot be transformed to power until it is materialized in foreign policy practice (Pollack, 2010). This is where Manners' ideas of Normative Power, which is based on constructivist arguments in International Relations theory, intervenes in the debate (see also Manners \& Whitman, 2016). Aimed at bridging the contention between the liberal approach 
based on ideational sources of power with the realist approach based on material sources, Manners identifies 'normative power' in terms of opinion, ideological, and norm-shaping forces that one state-more specifically, the European Union-possesses in world politics. Manners' idea resonates with the idea of "normative multipolarity", which argues that state power depends largely on states' ideational resources, such as a forceful adherence to international law and institutions and a strong sense of collective identity, and contested throughout states' involvement in diplomatic practices in world politics (Acharya, 2004).

This debate over conception of "power" has led this research to map the similar debate over "European Power". Recent studies on European Union's position in world politics posits EU power as a 'civilian' and later 'normative' power (Duchene, 1972; Bull, 1982; Manners, 2002). Maull (1990) conceptualises three elements of 'civilian power', namely: (1) the acceptance of cooperation with other political forces, rather than conflict, in the pursuit of international objectives; (2) the concentration on non-military means to secure national goals, and (3) a willingness to develop supranational structures to address critical issues in international politics (also quoted in Smith, 2005). This notion of 'civilian power' came into the theoretical debate when Hedley Bull, a prominent IR English School theorist, argued that the increasing role of EU in military and defence policy has led to the adoption of the notion of 'military power Europe'. He argued that the concept of 'civilian power' does not represent the realist concept of power, which has been defined as military power. Norms do not significantly construct EU's Foreign Policy as a major political force in world politics. Thus, with this realist approach, Bull argued that EU's power should be understood by how it can secure EU from external threat (Bull, 1982).

Ian Manners later challenged such arguments. According to Manners (2002), EU's power should be read as one ideational resource, which can be transformed as the normative basis of EU Foreign Policy in its relation to another region. EU as a 'giant' state 
that unites its ten member states constitutes a new discourse of power, which is based not only from a traditional form of "military power" but also the ideational foundations. There are four founding principles, which become the normative basis of EU: liberty, democracy, respect for human rights and fundamental freedoms, and rule of law. Those four principles, derived from the Treaty of European Union, then become important norms that constitute EU's power in its relation to other political forces in the world. Other than that, these principles also become the major campaign in EU's cooperation with states from different regions such as Southeast Asia.

Given these founding principles, Manners than argued that such foundations, which served as ideational basis of foreign policy is relevant to place EU in world politics. Addressing the multipolar world order, EU came with the opportunity to fulfil many spaces with its unique normative basis. EU has many ideational resources that build the identity of its foreign policy. According to Manners, EU's specific norms can be conceptualised as a changer of norms in the international system based on the 'so-called' normative power. In Manners' point of view, the principles constitute the normative basis of 'European power' that distinguishes EU's concept of power from another state's concept of power-particularly US-in their foreign policy. Manners finally concludes that the concept of normative power is the most suitable approach to understand EU's foreign policy and engagement with other actors in global politics.

From this viewpoint, Manners coined a new term, 'normative power'. This concept attempts to bridge Maull's-and also Duchene's - conception of 'power' to the normative foundations of European Union in its latest development, which is embedded in several EU's foundational treaties. In his essay, challenging Hedley Bull's scepticism over EU's civilian power, Manners (2002) stated that the power of EU is located in a debate between the 'idea forces' and 'ideological power' which is focused on the ideational character in EU's common principles (p. 239). This is, indeed, a constructivist 
argument. According to Manners, this ideational character shapes the direction of EU's foreign policy and subsequently spreads EU norms to all over the world through what he called as 'norms diffusion'.

Elements of Manners' idea of 'normative power' will be described as follows. First, European Power derives their concept on what they believe as ideology. According to Manners (2002), the European Union has some treaty foundations, which derive some norms, like the Treaty of EU (TEU), the Treaty of the Establishment of European Commission (TEC), and etc. These treaties form a new 'way' of EU Foreign Policy. Those norms become a 'spirit' to formulate EU Foreign Policy in many aspects of cooperation, especially in 'global south countries'-programs that become a socalled national interest-in the context of supranationalism. This 'normative power' strengthens EU's position in world politics.

Second, European Power is determined by its norm-shaping forces (Manners, 2002; Pollack, 2010). It is the ability to shape conceptions of "normal" in world affairs that makes EU's normative power operate in world politics. Consisting of many states that have played major roles in world politics, such as the United Kingdom, France, Germany, and many other countries, EU has been able to drive world politics and define its 'normality' based on its interests. On the other hand, with its 'gigantic' size and high influence, EU can also drive public opinion in the global context, thus 'normalize' the world under EU's leadership.

According to Manners, what makes EU different with other political forces in world politics is its ability to manage its material resources under certain norms. EU has formulated its foundational principles that guide its foreign policy-liberty, democracy, respect for human rights and fundamental freedom, and rule of law. We can see, according to Manners, the manifestation of these norms in some actions that EU has conducted in several countries. One of the examples provided by Manners was the case of the death penalty in the Philippines and Nepal. After voting in favour of the 
EU resolution Nepal abolished the penalty two months later, while the Philippines abstained from voting even though it still retained the penalty, but a year later it introduced a moratorium (Manners, 2002).

This case, according to Manners (2002), reflects how EU's normative power operates in world politics. EU's normative power is manifested through the combination of ideational bases, which are embedded in EU's foundational treaties, and its foreign relations with other countries. Since EU consists of many 'giant' states which have been considered as major political forces, and it has been politically involved in many issues in world politics, Manners suggested that norms have been central to the construction of EU's power. It is norms that drive EU's foreign policy and make their big size successfully operate in world politics.

Nevertheless, Ian Manners' conception on 'normative power' has also been widely criticized. Realists have been particularly critical of Manner's idealistic approach to EU's foreign policy by highlighting the importance of military and economic strength to tie down US hegemony in world politics, particularly after 9/11 (Pollack, 2010; Hyde-Price, 2006). A harsher critique even placed Manner's normative power as a justification of military-security dependence on the US - as several scholars implied, "the US makes the dinner and EU does the dishes" (Diez, 2005). Another critique accused 'normative power' of being immaterial and neglecting the political and economic aspects of 'power' (Pollack, 2010). Other critiques such as from Tilley (2012) suspect EU as having a 'double standard' in its human rights campaigns.

It is also important to consider that these criticisms have relied strongly upon the assumption that places EU as the subject in world politics. The normative power concept, as well as its Realist critics, according to Thomas Diez, have been very subjective in assessing EU's power due to its identification basis-EU as 'the I' and other parts of the world as 'the Other' (Diez, 2005). It thus creates a 'Eurocentric' tendency that places EU as the 'centre' of the world 
order. Understanding EU's external engagements through this Eurocentric lens will put the study of EU in danger of dismissing the subjectivity of the global south at the expense of "European subjects" (Bhambra, 2009). It is important, therefore, to discuss EU's power in different subjectivity relations-by decentring EU and discussing EU's power in other perspectives - and thus unpacking the ideological tendencies that become a backdrop of EU's concept of power. Michael Foucault's work on "governmentality will be helpful in unpacking those power relations in EU's international development and civil society strengthening programs in Indonesia.

\section{Alternative Framework: Understanding EU Power as "Global Governmentality"}

This article will make use of the concept of "governmentality" as an alternative to Manners' conception of normative power. Foucault defined government as the "conduct of conduct," a form of activity designed to shape personal, interpersonal and institutional conduct, as well as the conduct of political sovereignty (Foucault, 1991; Nadesan, 2008, pp. 15-16). Foucault argued that shifting regimes of government can be identified in part through shifting technologies and strategies of power. Rojas (2004) added the role of 'internationalised aid' as a new form of governmentality.

According to Rojas (2004, p. 99), power in the context of 'governmentality' is rationalized differently in terms of diverse modalities of government and specific knowledge associated with specific forms of rule. It constructs a new form of "developmentalism", in which the strategy incorporates the participatory planning, poverty alleviation, the strengthening power of civil society, but in the context of 'development' proposed by EU who diffuse their norms to their 'partners' and thus control the state indirectly through this strategy. Thus, 'development' in EU's programs has become a biopolitical tool that controls the 'global south subjects', and even constructs a new political subjectivity.

By using the concept of 'governmentality', this article 
argues that EU's engagement through civil society strengthening programs is a form of 'government' that EU aims to build, construct, and develop in Indonesia. Development and its Civil Society Strengthening Programs - that have been embedded in EU's international development strategy-is an important tool to biopolitically cultivate a particular subjectivity inherent in EU's normative framework. It thus can be perceived as a form of 'global governance' that leads EU to play a major role in governing the global south. From this point of view, EU's involvement in global development projects cannot be merely identified as 'normative power'. Otherwise their development projects, although driven by certain norms that have been developed earlier, have been central to the subjectivity of the global south. From this 'global southist' perspective, EU's power should be read as 'global governmentality' rather than 'normative power'.

How could EU govern the global south and thus create a new form of subjectivity? To analyse EU's strategy, it is important to follow Pollack (2012) to analyse EU's material form of power. Since EU is comprised of many prominent European states, EU can combine sources of funds from many 'rich countries' in Europe. The amount of financial assistance managed by the European Commission-EU's governing body'-is allocated to international development projects and is dedicated to help the global south countries who need financial aid or assistance. Consequently, EU can distribute their funds to states that need development and financial assistance. It is nonetheless creating a generosity power in EU's foreign policy.

However, it should also be noted that EU does not give development aid or assistance without conditionalities. There are some aspects and procedures to be committed to before 'partners' access financial assistance from EU, and one of them is 'good governance' conditionalities. These conditionalities thus become a 'bargaining position' for EU to campaign their norms, especially 'good governance', which promotes the principle of responsibility 
to govern in accountable manners. It contains several procedures and prerequisites that should be met by those who wish to submit proposals for funding. These prerequisites and procedures are given in order to guarantee responsibility, transparency, and other forms of good governance-typical preconditions proposed by International Development Regimes (Li, 2002). By giving incentives, EU has indirectly forced stakeholders in the country (including government) to learn about democratic responsibility. It also promotes an anticorruption spirit that has become a spectre in developing or lessdeveloped countries.

By using the concept of "governmentality", it can be understood that the concept of normative power constitutes a new method of 'governing' in the global south. The process of governmentality can be understood as follows: EU provides development assistance to any countries that are in favour with EU's norms. However, this financial assistance is not a 'free-of-charge' assistance. EU provides the assistance via its specific programs, prerequisites, and procedures-and thus placing its norms within development projects. In Indonesia, EU develops 'Civil Society Strengthening Programs' as a mean of development assistance. This unique program has been made to construct certain norms that are embedded within EU's foreign policy. By placing particular norms, the EU are able to advocate a kind of 'passive revolution' in order to maintain their hegemony in third-world countries. EU's development projects have also been used as a biopolitical tool to construct a model 'government through society' (Li, 2002; Harriss, 2003).

Based on this conceptual framework, this article argues that Manners' idea of normative power needs to be redefined as a possible act to transform another state and give some spaces to EU to manifest their interests in the form of 'government' and its 'governmental project'. EU power is manifested not only through foreign policy as a main tool, but also involves broader international engagements that emerged amid the structural transformation of world politics 
after the Cold War. The rise of 'post-Authoritarian' states after the Cold War gives the opportunity for EU to engage not only with their 'traditional' North American counterparts, but also with broader actors in the 'global south' (Merlingen 2006; Bretherton \& Vogler, 2009). In other words, EU's complex external engagement through development assistances and democracy promotion, along with EU's foreign policy in general, constitute a form of governmental project that aims to cultivate its norms in other part of the worlds through various cooperations and aids. It is therefore important to understand development cooperation and assistance as a political project (see Joseph, 2010).

The term 'governmental project' does not entirely have negative connotations. It to some extent could help beneficiary countries to undergo the democratic transition, thereby cultivating democratic culture of those states and preventing the 'authoritarian nostalgia' that seems to face post-authoritarian states in their transition towards democratisation (see also Huntington, 1997). However, the implementation of such development and democratic assistance also relates to social formation of EU's power in the global south, which is interconnected with EU's economic and security interests in the global south. From this critical perspective, this article will assess EU's 'governmental project' as manifested in its international development, democracy promotion, and, more specifically, the civil society strengthening programs in Indonesia.

\section{European Union and Civil Society Strengthening Programs in Indonesia}

Having established the framework of 'global governmentality' to understand EU's power, this article will proceed to explain how the EU's governmentality works through their civil society strengthening programs in Indonesia. In doing so, this article will start by understanding the role of 'civil society' in world politics. This section will be divided into two parts. The first part will discuss the origins of civil society engagement in world politics, particularly 
after the Cold War that lead to the 'third wave of democratisation' (Huntington, 1993). The second part will discuss EU's engagement of civil society in Indonesia through their international development and democracy promotion projects.

\section{The Origins of Civil Society Engagement in World Politics}

It is widely assumed that the end of the Cold War has been marked by the emergence of 'transnationalism', 'globalisation', and the plurality of actors in world politics. International Relations is not only monopolised by the 'state' as single actors, but also recognizes the role of 'non-state actors in world politics (Kegley, 2006; Widjojanto et al., 2007; Riss-Kappen, 1995). One of the important actors, that have emerged after the Cold War, is civil society - those who are identified as "voluntary associations deliberately seeking to shape the rules that govern aspects of social life' (Scholte, 2004). Civil Society has emerged in many postauthoritarian states as influential actors, following the so-called 'democratic transition' processes (Huntington, 1993). Since EU and other donor institutions have had 'democracy' as their foundational principles, Civil Society's engagement has been central in their frameworks for development. Thus, discourses of civil society within an institutionalised democratic process has been transnationalised alongside the democratisation process itself, leading to many donorled development projects that operate side-by-side with civil society's engagement.

Standard 'transition towards democratisation' literatures argue that strong and vibrant civil society is an important ingredient of cultivating democratic cultures in post-authoritarian states (Huntington, 1993; Diamond, 1999; Uhlin, 1997). Democracy should be followed by strong popular participation, which is institutionalised through the democratic political system (see Dahl, 1956). Participation needs engagement from citizens to actively participate in the political process. It is in this context democracy needs civil society organisations as a key variable in maintaining 
democratic political processes. Indonesia is often regarded as the best example of how vibrant civil societies will lead the country towards democratization (see Uhlin, 1993). After 1998, a democratic political change swept Indonesia and brought along several agendas to create a democratic state. This agenda, however, required many facilities and supports. Collaborations between Indonesian governments with several donor institutions whose aims to help Indonesia's development through loans and development assistances were crucial at this stage (see Carroll, 2012; Li, 2012). This cooperation was welcomed by many civil society organizations that had to deal with problems such as corruption, lack of capacity of government apparatuses, and poverty.

The transnationalization of civil society that appears in Indonesia gives some chances to EU and civil society both to meet and articulate their interest in mutualistic relations (Widjojanto et al., 2007). EU could distribute development funds and impose certain norms to Indonesia's development practices, while Civil Society could obtain financial support for their programs. This mutual interest has been made possible after 1998 due to several shifts in donor frameworks in distributing aids. Before 1998, donor's involvement in Indonesia had targeted Government and its technocratic infrastructures. However, since the reformasi, Civil Society and other non-state actors have been the main target of donor's development projects due to the so-called 'good governance' projects (Hadiwinata, 2003). Through several EU-funded projects, civil society comes to join in the EU scheme of 'international development policy' (Bossuyt, 2006). The cooperation between EU and civil society then becomes a modus operandi of EU to spread their norms in its development cooperation with another country. The importance of civil society can be seen in the community involvement endorsed by EU. Endorsement over public participation enables civil society organisations to be more involved in decisionmaking processes. 
It was started in EU's development policy. EU had formalised its relations with states from Africa, the Caribbean, and the AsiaPacific (later abbreviated as ACP) under the Cotonou Agreement, which was signed in June 2000. This agreement legally recognised the essential role that non-state actors can play in the development process. The purpose is not to oppose governments, but to foster dialogue and collaboration between the different development players (Bossuyt, 2006). This agreement has been the embryo of the so-called 'Civil Society Strengthening Programs' that are central in EU's international development frameworks. In November 2002, the European Commission published a new strategy that put more emphasis on the role of non-state actors within EU's development policy (see Hurt, 2006).

Thus, under the Cotonou Agreement and the following cooperations thatEU had signed after 2000 , civil society's involvement has played a major role in EU's international development frameworks. EU's democracy promotion in Africa, for instance, has also endorsed civil society's involvement to safeguard the democratic mechanism and development processes (Crawford, 2006, p. 143). Ghana can be a good example of this democracy promotion program. Following the signing of the Cotonou Agreement, the European Commission adopted a new Country Strategy Paper(CSP) that placed emphasis on civil society strengthening and assistance to NGOs. Projects are generally administered with local governments (District Assemblies), with some involvement from beneficiary communities, and thus encouraging grass-root stakeholders to be more involved in development processes (Crawford, 2006, p. 144).

\section{Civil Society Strengthening Programs and EU's International Development Projects in Indonesia}

Historically, before the Partnership \& Cooperation Agreement (PCA) signed in the late 2000s, the cooperation between EU and Indonesia was conducted under The Mission of the Republic of Indonesia to European Communities (PRIME) which was 
established in 1990. The mission's objective is to accommodate the growing needs for nurturing relations between Indonesia and the EU. EU-Indonesia Partnership \& Cooperation Agreement was firstly formalised and signed in 2003. In that PCA, EU agreed to support Non-State Actors to conduct capacity development and institutional strengthening for education stakeholders. The aim of this cooperation, according to this PCA, is to improve access to quality education and increase transparency and monitoring of education budgets. There are 6 on-going projects with Non-State Actors with a total EU support of more than $€ 1$ million, PCA reports.

Totally, there were at least 70 projects funded by EU, covering 8 sectors which have formed a cooperation basis in IndonesiaEU's PCA. Civil Society's involvement is included in democracy, government, and human rights sectors. There are several projects funded by EU in the context of civil society activities in Indonesia. There are, for example, advocacy programs for Special Autonomy Fund for the Implementation of Education Quality in Papua, partnerships among Government, Parliament and Civil Society in Support for Pro-Poor and Gender-Responsive Budget Initiatives in South Sulawesi, Capacity Building for Local CSOs to Enhance Democratic Participation and Representation in Aceh and Papua, and the Civil Society Engagement in Improving Quality and Access to Education.

In this article, I will take a deeper look at program samples in three sectors: education, anticorruption, and social empowerment. In the education sector, there was a project for Promoting Transparency, Accountability and Effectiveness in the Management of Education Deconcentration Fund. It was conducted by Pusat Studi Pengembangan Kawasan (PSPK) Tungal in 6 cities: Lampung, Semarang, Samarinda, Kupang, Makassar, and Jakarta. The purpose of this program is to promote transparency, accountability, and effectiveness in the management of the education deconcentration 
fund. PSPK Tungal worked from $01 / 2009$ to $01 / 2011$. $^{2}$ It is interesting to see the result-educational budgeting is in fact very corrupted because of the lack of transparency of the educational institution itself. Thus, the civil society strengthening program was concentrated on the budget monitoring and transparency so that the public can access information from the educational institutions.

We can see another program in education: Encouraging School Accountability System to Ensure School Service Affordability for the Poor. This program was conducted by PATTIRO (Pusat Telaah Dan Informasi Regional) in 3 regencies: Serang, Gresik, and Malang, funded for about $€ 171,899.95$ by EU. PATTIRO tried to promote an education expenditure system at schools that facilitate students of poor families to receive affordable education services by maintaining accountability of education fund usage at schools. ${ }^{3}$

In the anticorruption sector, there was also an advocacy support for Public Procurement Reform in Local Government by Promoting Stakeholders Participation as a Means of Corruption Eradication in Public Service Delivery. It was conducted in Purwakarta and Indramayu by Yayasan Bandung Trust Advisory Group from 2009 until 2010. EU contributed funding of $€ 121,112$ total. ${ }^{4}$ The purpose of this program was to reform public procurement in the endeavours of accomplishing good governance and preventing corruption through espousing local stakeholders' participation. In this sense, EU tried to prevent corruption by enhancing public participation. This approach-which is very similar with the neoliberal approach-sees corruption as a result of the lack of transparency from public institution and thus the institutional reform as well as greater public control should be encouraged. Thus, the effort to prevent corruption, according to EC, should be conducted through participation strengthening of civil society.

2 http://eeas.europa.eu/delegations/indonesia/projects/list_of_projects/172234_en.htm.

3 http://eeas.europa.eu/delegations/indonesia/projects/list_of_projects/172462_en.htm.

4 http://eeas.europa.eu/delegations/indonesia/projects/list_of_projects/172334_en.htm. 
Lastly, we should also see EU-funded programs in social empowerment. From 2010-2014, Bandung Institute of Governance Studies (BIGS) held a project to encourage local governments in implementing the National Action Plan on Human Rights (RANHAM) for 4 consecutive years in the framework of ECOSOC rights. Fulfilment in education, health and economic sectors were the main concerns of this program. Generally speaking, this program was a response to a government program RANHAM (Rencana Aksi Nasional tentang HAM) that was proposed by the local government. Focusing on economic and social rights, the program was conducted in Bandung and Cimahi, two regencies in West Java and fully supported by EU. ${ }^{5}$ Those programs, before being accepted to be funded, should follow some complicated procedures.

According to Amin Sudarsono (Interview, January 3, 2011), a former PATTIRO activist who conducted EU-funded projects several times in Malang, Gresik, and Serang, applicants were invited for a presentation in the EU office in Jakarta before applying for EU projects. The presentation was followed by a tender selection to see which proposals are suitable for financial supports. It is a complicated procedure. It required a high sense of responsibility to manage and report the project, since the program should be reported in detail, especially for the financial report (Interview, January 3, 2011). If an applicant won the tender, there should be a letter of interest and proposal summary sent to the EU office. It is then selected and revised by EU Commission (there was another tender for the revision). After the second tender, applicants sent a complete proposal with the budget. Then the program was conducted with some periodic evaluations. If the program was fulfilled, the project manager should send a responsibility report to EU with the budget usage explanation. EU requires professionality and accountability to select the right persons to handle the project.

http://eeas.europa.eu/delegations/indonesia/projects/list_of_projects/212707_en.htm 
However, these EU-funded programs should also be analysed in a different perspective. What is the primary purpose of EU in spreading some fresh financial assistance to civil society organizations in funding their projects? What is the objective of the civil society organization in participating in those projects? What is the relationship between Civil Society Strengthening Programs with the construction of EU's global governmental project in the global south? The following part will analyse the formation EU's politics of global governmentality through their Civil Society's Strengthening Programs in Indonesia.

\section{Not Necessarily Normative? A Critical Assessment of European Union's Engagement of Civil Society in Indonesia}

EU-Indonesia Cooperation in Civil Society Strengthening Programs that had been presented before cannot be separated from EU's political interests in supporting Indonesia's development programs and assisting its democratic transitions. This section will apply the 'governmentality' approach in analysing EU's Civil Society Strengthening Programs in Indonesia. As presented in the previous part, civil society strengthening programs constitute a part of EU's democracy promotion to newly democratic states. Even though it contributes to develop democratization processes in Indonesia, there are also several aspects that should be criticized in the program.

This article will be departing from the discussion of EU's power. From the 'normative power' lens, as previously argued by Ian Manners, power should be understood on the basis of EU's ability to define 'what is normal' in world politics. In other words, we can say that EU's power relied upon the 'normalization process'-or in constructivist perspective, on how to diffuse norms to the real world. As argued by Ian Manners, EU works as a 'norms promoter' who has been able to use force in favour of redefining international norms in its own image (cited in Fiott, 2011). The particular norms that EU promotes, in the case of Indonesia, are democratic norms, 
which are based upon the premise of popular participation and the importance of a vibrant and strong civil society in the country (see Kurki, 2011).

In the Indonesian case, the governmentality process operates in the international development projects. EU shared many funds to develop and introduce Indonesian society to good governance, education, social empowerment, and anticorruption projects (EC, 2009). In this context, EU used the "third actor" to conduct the project - the Civil Society. However, Civil Society does not implement the project on their self-defined interests; they have to meet EU's prerequisites and procedures. This process has been described by Foucault as technologies of the self or biopolitics. Civil Society played a major role in employing the technologies of the self by doing advocacy under certain norms that had been imposed in funding and its procedures. The degree of successfulness is measured through some measurements provided by the donors-it involves local consultants in the process. ${ }^{6}$ Thus, within this mechanism, the Civil Society Strengthening Programs along with its complicated procedures and prerequisites have been an effective biopolitical tool that controls Indonesia's development practice in appropriation of EU's norms.

Therefore, Civil Society Strengthening Programs have been embedded with EU's international development strategies, which are supported by financial assistances that, as previously discussed, were given to Indonesian civil society. By providing some grants and projects, EU has been able to diffuse its norms and also drive the socio-political changes in Indonesia, which did not only appear in terms of corruption eradications, poverty alleviations, and many other programs, but also in a formation of a new 'discourse' of development. Such norms that EU proposed were thus diffused

6 For instances, there are many publications from civil society organizations who have successfully conducted advocacy with financial supports from donor institutions. EU and the World Bank also published some success stories that has been made 'best practice' for Civil Society to do advocacy under donor's assistances. 
in specific projects that had been conducted by CSOs under EU's prerequisites. Thus, the CSOs independently managed the projects under strict circumstances given by EU.

Consider, for example, the case of Public Procurement Reform in Local Government by Promoting Stakeholders Participation as a Means of Corruption Eradication in Public Service Delivery. The European Commission had mentioned that the aim of this program was to develop a reliable procurement system in the Indramayu and Purwakarta districts that underscores the principles of FATCEO (Fairness, Accountability, Transparency, Competition, Efficiency/Effectiveness, Openness) and easy access. To that end, the European Commission provides technical assistance to incorporate community participation at all stages, therefore ensuring community participations in public service delivery in accordance with the principles of transparency, accountability, and broader good governance.

This project highlights how the European Commission promotes their perspective of transparency and accountability in public delivery through two particular strategies: the use of 'procurement'-or more broadly 'technological tools'-and stakeholders engagement (see Greenwood, 2003). The process highlights the governmental processes that enable EU not only to deliver its norms to beneficiary countries, but also to create a system of democratic accountability in the grass-roots level. The combination of the use of 'technological tools' and democratic systems of participation is promoted as a 'model' for public management in the 'global south', which is embedded in EU-funded programs in Indramayu and Purwakarta. The principles of FATCEO (Fairness, Accountability, Transparency, Competition, Efficiency/ Effectiveness, Openness) represent the normative framework that is put to work through EU's technical assistance toward greater community participation in managing the public procurement.

The case of Public Procurement Reform in Local Government by Promoting Stakeholders Participation as a Means of Corruption 
Eradication in Public Service Delivery illustrates two ways in which Civil Society engages with EU, which exposes the particular form of "governmentality" that EU aims to promote in Indonesia. First, Civil Society is central in diffusing EU's norms to the real world, and thus creating some degrees of normality. In the process, EU will be able to strengthen civil society capacity in conducting advocacy, particularly in several issues related to local democratization, respect for human rights, and good governance. Thus, projects that are funded by EU can lead to social change. From such perspectives, EU is able to cultivate particular subjectivities (such as "good governance") through financial assistances to NGOs that lead to their active participation in influencing the practice of local governance.

From this point of view, "normative power" is not necessarily "normative", in the sense that it always goes hand-in-hand with a material form of power. Therefore, normative power could work only if there are reciprocal relationships between 'norms'-as a main source of power with a strong economy or even diplomacy that supports the norms diffusion in the global south. It is in this context some analyses of EU's international development practices stress how important it is to understand how EU develops their bases of 'normative power'.

Second, in the procedural level, EU funding for several projects also creates some practices of "norm internalization" for Indonesia Civil Society. The procedure to access those fundings is not as simple as fresh financial assistance for example that given by China to Angola. EU gives some prerequisites that are to be fulfilled by candidates who wish to apply for the project. A strict procedure creates responsibility for Civil Society Organizations. In a wider context, EU seems to provide a kind of 'education' for Indonesians to be accountable in using the funds, so that the corruption can be prevented and minimalised. EU sees 'accountability' as a belief in the neo-liberal perspective that sees the best way to combat corruption and prevent the dysfunction of state apparatuses is by increasing 
public control. It is why EU introduced 'good governance' as a specific norm that entails many aspects of accountability and thus involving Civil Society in the process.

The main benefit that they can gain is financial benefits. Civil Society Organisations will be able to find some financial supports to operationalise their programs. Through financial supports provided by EU, their objectives can be obtained. The second benefit is related to the making of a democratic environment that enables civil society to be more involved in decision-making processes, and thus minimizing risks of confrontation with the governments.

The normative power approach seems to overlook this question by providing only a little concern regarding the global south's perspective. Such relations between EU and Indonesia's CSOs will lead to the constitution of identity, which involves the construction of 'the I' and 'the Other' (Diez, 2005). The normative power approach has overlooked the subjectivity of Indonesia's CSOs that has just reappeared in Indonesia's democratic transition processes. Thus, the question of 'identity' should be addressed in a critical perspective. It is within this context the concept of 'governmentality' is useful. Foucault, for example, argues that certain norms that are imposed in a society are in fact an inseparable part of liberal governmentality, which recognizes that social fields - the state, the market, and population-are heterogeneous spaces constituted in relation to multiple systems of power, networks of control, and strategies of resistance (Nadesan, 2008: 10). The externality of the law was supplemented and replaced by the internality of "norm"in which Foucault linked it with the relations of power to persuade society (2008: 22 ).

EU's governmentality was also made possible by the decentralization and regional autonomy context that has been established in Indonesia since 1999. ${ }^{7}$ Hadiz (2010: 69) argued that

For clearer explanations on Regional Autonomy and social development practices in Indonesia, see Hadiz (2010), Erb and Sulistyanto (2009), or Carroll (2012). 
the decentralization projects in Indonesia also were followed by some institutional changes, which were driven by external forces such as the World Bank and EU. There were at least twelve institutional changes that occurred in Indonesia after the reformasi, including the establishment of the kabupaten and the kota, as the focal points of regional governance, and decentralization of power-such as budgeting - to enable the kabupaten and kota government to manage their own resources. Those changes also include the ability of local government (kabupaten) to secure loans from the Special Allocation Grant (DAK) provided by the central government through which special regional initiatives could be funded (2010: 78-79). In his previous article, Hadiz also argued that the decentralization scheme, which is advocated by external forces such as The World Bank and European Union created many contradictions, especially in political economic relations in local politics, which formed a new political hybrid of the old New Order oligarchy (Hadiz, 2004).

Thus, it can be concluded that the actual basis of EU's power is located within the implementation processes of development assistance programs instead of certain norms imposed on those programs. From the perspective of 'governmentality', the way in which EU bases their power does not necessarily rely solely upon the promotion of 'norms' but also in the way they engage with the community through aid giving practices, technical assistances, and more importantly international development programs funded by EU. The manifestation of EU's actual power, within this multifaceted approach, is the construction of 'post-authoritarian' Indonesian subjectivity that was built upon Civil Society's involvement and government's obedience to EU's tight procedures. Civil Society constitutes the technologies of the self and its role is central to EU's governmentality processes. The main goal of EU's motivation, in this context, can be tracked down to its neoliberal approach that is embedded in 'good governance' and decentralization politics that have been implemented in Indonesia since 1999. Further studies are required to breakdown and delineate this neoliberal vision. 
Nevertheless, it is obvious that EU's governmentality cannot be separated from the so-called 'neoliberal development policy' that has been a global consensus in post-Cold War world politics, even though it is operated in a softer manner.

\section{Conclusion}

This article has analysed EU's Civil Society Strengthening Programs in Indonesia and how it relates to the projection of EU governmentality in global politics. Two conclusions could be generated. First, EU's power in the developing countries, more specifically in Indonesia, operates through advocacy projects conducted by Civil Society Organizations. In the Indonesian context, civil society organization's activities significantly improved after the reformasi served to guide the democratization process. While the European Union believes in democracy as its fundamental norm, it assists the advocacy from Indonesian Civil Society Organizations through various financial grants. It therefore constructs power relations between the 'funded' donor programs with the EU's democracy promotion agenda that is embedded in its foreign policy.

Second, the purpose of EU in giving incentives to those projects is not purely 'normative'. Rather, it also contains particular political programs in the broader global context. From the "governmentality" perspective, it can be concluded that EU's Civil Society's Strengthening Programs are also considered a tool to construct particular modes of subjectivity of Indonesia's Civil Society. By analysing the strict procedures and prerequisites that EU apply in order to impose certain norms in its projects, EU's normative power is basically political. This mode of governmentality, which has been practiced by EU in its emerging international development projects, has led to a shifting paradigm of power in International Relations that does not necessarily rely upon state 'power', but also incorporates more complex techniques, tools, and strategies. The case of EU's engagement of civil society in Indonesia exemplifies this argument by reflecting the construction of EU power not only in 
traditional diplomatic or military strengths, but also in the practices of international development and democracy promotion.

Viewed from this perspective, this article has acquired two theoretical implications of the conceptualization of 'power' in global politics, particularly those related to the European Union and the 'Global South': First, 'power' cannot be understood merely on its 'material' or juridico-institutional basis, but also on its influence on the making of a particular society. It is thus important to identify 'power' in diverse and multiple aspects. Second, we need to consider aid giving practices, which are accessed by civil society organizations, as a strategy of 'governmentality' that is constitutive to the construction of EU's normative framework and political subjectivity in the global south. With the essential help of civil society as the executor of such programs, EU has been able thus to confront 'stateled' development policy and narrate 'good governance'-which is inherent in the neoliberal logic of development - as a framework of development through technical and financial assistances. Therefore, we could conclude that EU's Civil Society Strengthening Programs is also constitutive to the neoliberal development model as promoted by the European Union. 


\section{References}

Acharya, A. (2004). Regional Security in a Multipolar World: European Union in Global Perspective. FES Briefing Paper, Berlin: Frederich Ebert Stiftung.

Bretherton, C., \& Vogler, J. (1999). The European Union as a Global Actor. London: Routledge.

Bossuyt, J. (2006). "Mainstreaming Civil Society in ACP-EU Development Cooperation" in Lister, M. and Carbone, M. (ed). New Pathways in International Development: Gender and Civil Society in EU Policy. Hampshire and Burlington: Ashgate.

Bull, H. (1982). Civilian Power Europe: A Contradiction in Terms ?. Journal of Common Market Studies, 12 (2): 149-164.

Bulmer, S., \& Joseph, J. (2016). European Integration in Crisis? Of Supranational Integration, Hegemonic Projects and Domestic Politics. European Journal of International Relations. Online First View.1354066115612558.

Bhambra, G. K. (2009). "Postcolonial Europe, or Understanding Europe in Times of The Postcolonial" in Rumford, C. (eds). The SAGE Handbook of European studies. London: Sage Publications.

Carbone, M. (2010). The European Union, Good Governance and Aid Co-ordination. Third World Quarterly, 31(1), 13-29.

Carroll, T. (2010). Delusions of Development: The World Bank and the PostWashington Consensus in Southeast Asia. Hampshire: Palgrave.

Carroll, T. (2012). Neoliberal Development Policy in Asia Beyond the postWashington Consensus. Jakarta: TIFA and INFID.

Casarini, N. (2007). "The Making of European Union's Strategy Towards Asia" in Casarini, N. and Musu, C. (eds). European Foreign Policy in an Evolving International System: The Road Towards Convergence. Hampshire and New York: Palgrave.

Chandler, D., \& Richmond, O. (2015). Contesting Post liberalism: Governmentality or Emancipation?. Journal of International Relations and Development, 18(1), 1-24.

Crawford, G. (2006). "European Union and Strengthening Civil Society in Africa" in Lister, M. and Carbone, M. (ed). New Pathways in International Development: Gender and Civil Society in EU Policy. Hampshire and Burlington: Ashgate.

Dahl, R. A. (1956/2013). A Preface to Democratic Theory. University of Chicago Press.

Diez, T. (2005). Constructing the Self and Changing Others: Reconsidering Normative Power Europe'. Millennium, 33(3), 613-636. 
Duchêne, F. (1973). "The European Community and The Uncertainties of Interdependence" In Kohnstamm, M. \& Hager, W. (eds). A Nation Writ Large? Foreign Policy Problems before European Community. London: Palgrave Macmillan UK.

Edkins, J. "Poststructuralism" in Martin Griffith. (ed). (2007). International Relations Theory for $21^{\text {st }}$ Century. New York and Canada: Routledge.

Elgström, O. (2007). "European Union as a Leader in International Multilateral Negotiations - a Problematic Aspiration?" International Relations 21 (3): 445-458. http://ire.sagepub.com Accessed on February 23, 2009.

Erb, M. \& Sulistyanto, P. (2009). "Indonesia and the Quest for "Democracy" in Erb, M. and Sulistyanto, P. (eds). Deepening Democracy in Indonesia? Direct Elections for Local Leaders. Singapore: ISEAS.

European Union. (2016). Press Release on Indonesia-European Union Partnership \& Cooperation Agreement. Document accessed from . http://europa.eu/

European Union Delegates to Indonesia, Brunei Darussalam, and ASEAN. (2016). Project Overview. Document accessed from http://eeas. europa.eu/

Fiott, D. (2011). European Union's Normative Power in a Multipolar World. EUSA Biennial Conference 2011. Boston, EUSA.

Foucault, M. (1972). The Archaeology of Knowledge. London: Routledge.

Foucault, M. (1978). Nietzsche, Genealogy, History. Semiotexte, 3(1): 7894.

Foucault, M. (1991). "Governmentality" in Akhil Gupta (ed). Anthropology of The State. New York: Blackwell.

Gill, S. (2000). "The Constitution of Global Capitalism". The Capitalist World, Past and Present, Los Angeles: ISA.

Gillespie, R, \& Youngs, R. (2002). "Themes in European Democracy Promotion" in Gillespie, R and Youngs, R. (eds). European Union and Democracy Promotion: The Case of North Africa. London and Oregon: Frank Cass.

Greenwood, J. (2003). Interest Representation in the European Union. Palgrave Macmillan.

Hadiwinata, B. (2003). The Politics of NGOs in Indonesia: Developing Democracy and Managing a Movement. London: Routledge.

Hadiz, VR. (2004). "Decentralization and Democracy in Indonesia: A Critique of Neo-Institutional Perspectives".Development and Change 35 (2): 697-718.

Hadiz, VR. (2010). Localising Power in Post-Authoritarian Indonesia: A Southeast Asian Perspective. Stanford: Stanford University Press.

Hamilton, S. (2014). Add Foucault and Stir? The Perils and Promise of 
Governmentality and The Global. European Review of International Studies, 39 (2): 129-141.

Harriss, J. (2003). Depoliticizing Development: The World Bank and Social Capital. Delhi: Left Word.

Hurt, S.G. (2006). "Civil Society and European Union Development Policy" in Lister, M. and Carbone, M. (ed). New Pathways in International Development: Gender and Civil Society in EU Policy. Hampshire and Burlington: Ashgate.

Huntington, S.P. (1993). The Third Wave: Democratization in The Late Twentieth Century. Norman: University of Oklahoma Press.

Hyde-Price, A. (2006). 'Normative' Power Europe: A Realist Critique. Journal of European public policy, 13(2), 217-234.

Joseph, J. (2009). Governmentality of What? Populations, States and International Organisations. Global Society, 23(4), 413-427.

Joseph, J. (2012). The Social in The Global: Social Theory, Governmentality and Global Politics. Cambridge University Press.

Kendall, G. (2004). 'Global Networks, International Networks, Actor Networks' in Larner, W and Walters, W. (eds). Global Governmentality: Governing International Spaces. (London: Routledge).

Kegley, CW. \& Wittkopf, ER. (2006). World Politics: Trends and Transformation. Belmont: Thomson-Wadsworth, third edition, revised.

Kiersey, NJ. \& Stokes, D. (2010). Foucault and International Relations: New Critical Engagements. Abingdon: Routledge.

Kurki, M. (2011). "Governmentality and EU Democracy Promotion: The European Instrument for Democracy and Human Rights and The Construction of Democratic Civil Societies". International Political

Larner, W. \& Walters, W. (2009). 'Introduction: Global Governmentality: Governing International Spaces' in Larner, W and Walters, W. (eds). Global Governmentality: Governing International Spaces. (London: Routledge).

Li, TM. (2002). Engaging Simplifications: Community-Based Resource Management, Market Processes and State Agendas in Upland Southeast Asia. World Development, 30(2): 265-283.

Li, TM. (2006). "Neo-Liberal Strategies of Government Through Community: The Social Development Program of The World Bank in Indonesia". IILJ Working Paper 2. New York: Institute for International Law and Justice.

Li, TM. (2007). The Will to Improve: Governmentality, Development, and The Practice of Politics. Durham: Duke University Press. Translated to Bahasa Indonesia by Pujo Semedi and Hery Santoso. 
Manners, I. (2002). "Normative Power Europe: A Contradiction in Terms?" Journal of Common Market Studies, 40 (2): 235-258.

Manners, I. (2006). Normative Power Europe Reconsidered: Beyond the Crossroads. Journal of European public policy, 13(2): 182-199.

Manners, I., \& Whitman, R. (2016). Another Theory is Possible: Dissident Voices in Theorising Europe. JCMS: Journal of Common Market Studies, 54(1), 3-18.

Mearsheimer, J. J. (2001). The Tragedy of Great Power Politics. WW Norton \& Company.

Maull, H. W. (1990). Germany and Japan: The New Civilian Powers. Foreign Affairs, 69(5), 91-106.

Merlingen, M. (2006). Foucault and World Politics: Promises and Challenges of Extending Governmentality Theory to The European and Beyond. Millennium, 35(1), 181-196.

Morgenthau, H. J. (1948). The Problem of Sovereignty Reconsidered. Columbia Law Review, 48(3), 341-365.

Nadesan, NH. (2008). Governmentality, Biopower, and Everyday Life. London: Routledge.

Neumann, I. B., \& Sending, O. J. (2010). Governing the Global Polity: Practice, Mentality, Rationality. Michigan: University of Michigan Press.

Nye Jr, JS. (2002). "The Paradox of American Power: Why the World's Only Superpower Can't Go It Alone". Oxford: Oxford University Press.

Pollack, M. (2010). "Living in a Material World: A Critique of "Normative Power Europe" EUSA Review 23 (2):3-6.

Risse-Kappen, T. (1995). Bringing Transnational Relations Back In: Non-state Actors, Domestic Structures and International Institutions. Cambridge: Cambridge University Press.

Rojas, C. (2004). "Governing Through the Social: Representations of Poverty and Global Governmentality". Wendy Larner and William Walters (eds). Global Governmentality: Governing International Spaces. New York and Canada: Routledge).

Scholte, JA. (2004). 'Civil Society and Democratically Accountable Global Governance', Government and Opposition 39 (2). 211-33.

Shapiro, IJ. (1989). "Textualizing Global Politics" in James Der Derian and Ian J. Shapiro. Intertextual/International Relations. Ontario: McMillan.

Sheridan, A. (2005). Michael Foucault: The Will to Truth. London: Routledge.

Smith, K. E. (2005). Still 'Civilian Power EU'?. European Foreign Policy Unit Working Paper, 1(2005), 202-005-1.

Sjursen, H. (2006). "EU as 'Normative Power: How Can This Be?" Journal 
of European Public Policy 13 (2): 235-251.

Tilley, R. (2012). Normative Power Europe and Human Rights: A Critical Analysis. POLIS Journal, 7: 420-449.

Umar, A. R. M. (2016). A Genealogy of 'Moderate Islam': Governmentality and Discourses of Islam in Indonesia's Foreign Policy. Studia Islamika, 23(3): 399-430.

Uhlin, A. (1993). Transnational Democratic Diffusion and Indonesian Democracy Discourses. Third World Quarterly, 14(3), 517-544.

Vrasti, W. (2013). Universal but Not Truly 'Global': Governmentality, Economic Liberalism, and The International. Review of International Studies, 39(01), 49-69.

Widjojanto, A et al. (2007). Transnasionalisasi Masyarakat Sipil. Yogyakarta: LKiS.

Zaborowski, M. (2006). EU as A Global Power. Warsaw: EU Institute for Security Studies and European Centre Natolin. 